\title{
Lemierre syndrome
}

\section{More than "the forgotten disease"}
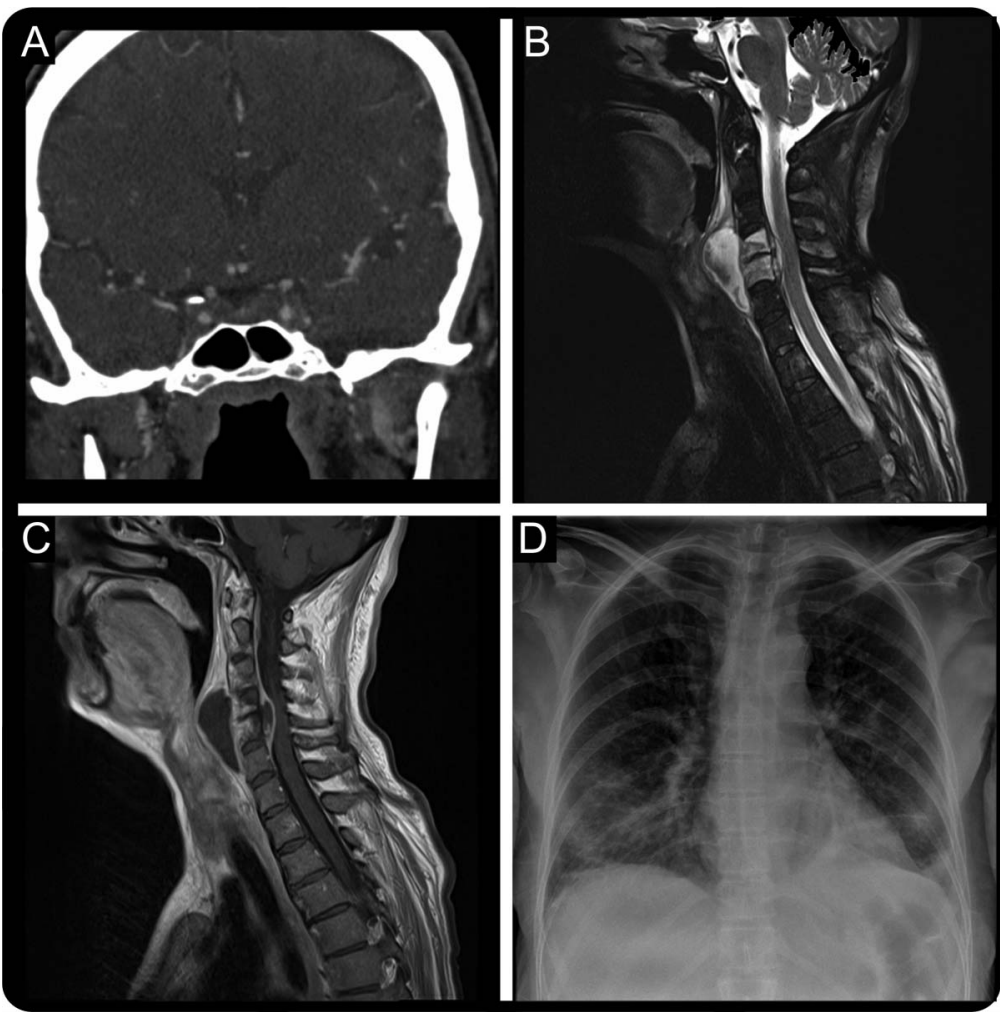

CT venous angiography with scan delay documented a filling defect in cavernous sinus due to a thrombosis (multiplanar reconstruction-coronal view, A). Sagittal T2-weighted MRI (B) and postcontrast T1 sequences (C) reveal a retropharyngeal abscess and an epidural empyema with intense dural enhancement. Chest x-ray shows multiple basal pulmonary opacities (D).

A 54-year-old woman presented with fever, spasmodic torticollis, ptosis, and chemosis in her left eye. CT venous angiography revealed cavernous sinus thrombosis (CST) and left internal jugular vein thrombosis (IJVT) (figure, A), cervical MRI detected a retropharyngeal abscess and epidural empyema (figure, B and $\mathrm{C}$ ), and chest $\mathrm{x}$-ray showed multiple pulmonary opacities (figure, D). The clinical/radiologic picture, due to anaerobic septicemia, was consistent with Lemierre syndrome (LS), the so-called "forgotten disease." Extensive neuroimaging studies are mandatory to detect an abscess in the neck of patients with CST and IJVT for early diagnosis and treatment. LS is still relevant today.

Nicola Morelli, MD, Eugenia Rota, MD, Daria Sacchini, MD, Giovanna Ratti, MD, Antonino Cassi, MD, Franco Feraboli, MD, Marina Biondi, MD, Emanuele Michieletti, MD, Donata Guidetti, MD

From the Guglielmo da Saliceto Hospital, Piacenza, Italy.

All authors contributed equally to the manuscript.

Author contributions: Nicola Morelli: study concept or design, accepts responsibility for conduct of research and final approval, acquisition of data. Eugenia Rota: drafting/revising the manuscript, accepts responsibility for conduct of research and final approval, acquisition of data, study supervision. Daria Sacchini: analysis or interpretation of data, accepts responsibility for conduct of research and final approval, statistical analysis. Giovanna Ratti: study concept or design, accepts responsibility for conduct of research and final approval. Antonino Cassi: analysis or interpretation of data, accepts responsibility for conduct of research and final approval. Franco Feraboli: study concept or design, accepts responsibility for conduct of research and final approval. Marina Biondi: analysis or 
interpretation of data, accepts responsibility for conduct of research and final approval, acquisition of data. Emanuele Michieletti: analysis or interpretation of data, accepts responsibility for conduct of research and final approval. Donata Guidetti: drafting/revising the manuscript, accepts responsibility for conduct of research and final approval.

Study funding: No targeted funding reported.

Disclosure: The authors report no disclosures relevant to the manuscript. Go to Neurology.org for full disclosures.

Correspondence to Dr. Morelli: n.morelli@inwind.it

1. Vargiami ED, Zafeiriou DI. The Lemierre’s syndrome. Eur J Pediatr 2010;169:411-414.

\section{NeuroImages Are Free at www.neurology.org!}

All Neurology ${ }^{\circledR}$ NeuroImages can now be freely accessed on the Neurology Web site. See them at www.neurology.org, where you can also sign up for journal email alerts and check out other online features, including the Resident \& Fellow section, Neurology: Clinical Practice, and the weekly Neurology Podcasts. 


\title{
Neurology
}

\author{
Lemierre syndrome: More than "the forgotten disease" \\ Nicola Morelli, Eugenia Rota, Daria Sacchini, et al. \\ Neurology 2013;81;1179-1180 \\ DOI 10.1212/WNL.0b013e3182a55f30
}

This information is current as of September 23, 2013

\section{Updated Information \& Services}

References

Citations

Subspecialty Collections

Permissions \& Licensing

Reprints including high resolution figures, can be found at: http://n.neurology.org/content/81/13/1179.full

This article cites 1 articles, 0 of which you can access for free at: http://n.neurology.org/content/81/13/1179.full\#ref-list-1

This article has been cited by 1 HighWire-hosted articles: http://n.neurology.org/content/81/13/1179.full\#\#otherarticles

This article, along with others on similar topics, appears in the following collection(s):

Abscess

http://n.neurology.org/cgi/collection/abscess

Bacterial infections

http://n.neurology.org/cgi/collection/bacterial_infections

Cerebral venous thrombosis

http://n.neurology.org/cgi/collection/cerebral_venous_thrombosis

CT

http://n.neurology.org/cgi/collection/ct

MRI

http://n.neurology.org/cgi/collection/mri

Information about reproducing this article in parts (figures,tables) or in its entirety can be found online at:

http://www.neurology.org/about/about_the_journal\#permissions

Information about ordering reprints can be found online:

http://n.neurology.org/subscribers/advertise

Neurology ${ }^{\circledR}$ is the official journal of the American Academy of Neurology. Published continuously since 1951, it is now a weekly with 48 issues per year. Copyright () 2013 American Academy of Neurology. All rights reserved. Print ISSN: 0028-3878. Online ISSN: 1526-632X.

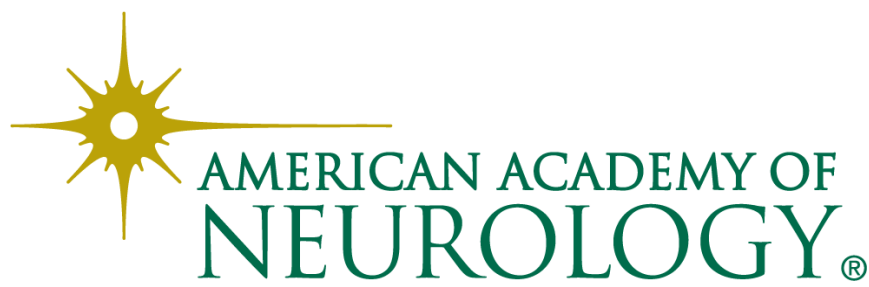

